\title{
Maize Production and Soil Properties Change in Alley Cropping System at Different Nitrogen Levels
}

\author{
Md. Abiar Rahman ${ }^{1 *}$, Md. Giashuddin Miah ${ }^{1}$ and Hisashi Yahata ${ }^{2}$ \\ ${ }^{1}$ Department of Agroforestry and Environment, Bangabandhu Sheikh Mujibur Rahman Agricultural University, \\ Gazipur-1706, Bangladesh, ${ }^{2}$ Institute of Tropical Agriculture, Kyushu University, Fukuoka 812-8581, Japan \\ *Corresponding author and Email: abiarbd@yahoo.com
}

\begin{abstract}
Productivity of maize and soil properties change under alley cropping system consisting of four woody species (Gliricidia sepium, Leucaena leucocephala, Cajanus cajan and Senna siamea) at different nitrogen levels $(0,25,50,75$ and $100 \%$ of recommended rate) were studied in the floodplain ecosystem of Bangladesh. Comparative growth performance of four woody species after pruning showed that $L$. leucocephala attained the highest height, while $C$. cajan produced the maximum number of branches. Higher and almost similar amount of pruned materials (PM) were obtained from S. siamea, G. sepium and $C$. cajan species. In general, maize yield increased with the increase in $\mathrm{N}$ level irrespective of added PM. However, $100 \%$ N plus PM, 75\% N plus PM and 100\% N without PM (control) produced similar yields. The grain yield of maize obtained from $G$. sepium alley was $2.82,4.13$ and $5.81 \%$ higher over those of L. leucocephala, C. cajan and S. siamea, respectively. Across the alley, only one row of maize in the vicinity of the woody species was affected significantly. There was an increasing trend in soil properties in terms of organic $\mathrm{C}$, total $\mathrm{N}$ and CEC in alley cropping treatments especially in G. sepium and L. leucocephala alleys compared to the initial and control soils. Therefore, one fourth chemical $\mathrm{N}$ fertilizer can be saved without significant yield loss in maize production in alley cropping system.
\end{abstract}

Keywords: Alley cropping, woody species, prune materials, maize yield, soil properties

\section{Introduction}

Supply of balanced nutrients to the soil is essential to get desired crop yield. A good soil should have at least $2.5 \%$ organic matter, but in Bangladesh about $60 \%$ of the cropped land has organic matter less than critical level of $1 \%$, which indicates poor soil condition (Hossain and Kashem, 1997). It is believed that the declining productivity of the soils is the result of depletion of organic matter due to increasing cropping intensity, use of lower quantity of organic manure and little or no use of green manure (BARC, 2005). Farmers usually apply decomposed cow dung and farm yard manure in soil as organic matter. However, the production of organic matter in Bangladesh is not enough to meet the requirement. Moreover, farmers also use cow dung as fuel. On the contrary, poor farmers can not afford to buy expensive chemical inputs including fertilizers and pesticides while rich farmers are applying over doses. Among the chemical fertilizers, the use of nitrogenous fertilizer accounts for about $88 \%$ (BBS, 1998). As a result agro-ecosystem is loosing its integrity and fertility as well as causing the environmental degradation. Suitable farming system that would help to improve crop yield as well as restore soil fertility should therefore, be developed. Organic farming was found as a reaction against agricultural practices that had the potential of harm to nature and human health (Harwood, 1990). Agroforestry, especially alley cropping, can help more efficiently to manage agriculture production system (Jordan, 2004). 
Alley cropping is one of agroforestry systems that is intended to place trees within cropping system. In this system, arable crops are grown in between the hedges of woody species, preferably legumes, that are regularly cut back to minimize the competition between tree and crop for light, water and nutrients (Tossah el al., 1999). The pruned materials from tree are incorporated into soil at planting and/or during the cropping period so that pruned materials release nutrients into the soil and improve the physico-chemical properties of soil; and ultimately improve the growth and development of the associated crops (Miah, 1993). In alley cropping system, fast growing leguminous woody species are grown because they usually recycle nutrients, contribute biologically fixed nitrogen, and provide fuel, fodder and timber which are presently harvested from dwindling forests (Kang et al., 1984).

Yield improvement in maize through alley cropping with different woody species has been reported in many countries (Chamshama et al., 1998; Tossah et al., 1999; Aihou et al., 1999; Friday and Fownes, 2002). Alley cropping system could restore soil fertility and increase crop yield. Since pruned materials are added into soil organic matter as well as soil nutrients may be added to the soil through leaf decomposition and nutrient release. Thus, nitrogen fertilizer can be saved through the application of suitable tree leaves in alley cropping system. Subsistence farmers, who could not efford to buy expensive chemical fertilizers, could be benefited by using alley cropping. However, the potential of alley cropping in Bangladesh has not yet been investigated for crop production. The objectives of the study were to: (1) compare the growth behavior of the four woody species after pruning, (2) evaluate the yield of maize in alley cropping system at different $\mathrm{N}$ levels after incorporation of pruned materials, and (3) examine the soil properties change before and after maize production in alley cropping system.

\section{Materials and Methods}

\subsection{Study site}

The experiment was conducted at the Bangabandhu Sheikh Mujibur Rahman
Agricultural University (BSMRAU) farm $\left(24^{\circ} 0^{\prime} \mathrm{N}\right.$ latitude and $90^{\circ} 25^{\prime} \mathrm{E}$ longitude) from June 1998 to April 1999. The soil was a shallow red terrace under Salna series, but the texture has been changed to a loam by deposition of recent alluvial soil. The experimental area has subtropical climate characterized by heavy rainfall from May to September and scantly rainfall during rest of the year. The climatic condition in the study area during the experimentation has been shown in Fig 1.

\subsection{Experimental design and treatments}

The experiment was laid out in a split-split plot design with three replications. Four woody species (Gliricidia sepium, Leucaena leucocephala, Cajanus cajan and Senna siamea) were arranged in main plot, while five nitrogen levels namely $0,25,50,75$ and $100 \%$ of recommended $\mathrm{N}\left(100 \mathrm{~kg} \mathrm{ha}^{-1}\right)$ and distances from the woody species base $(50,100$ and $150 \mathrm{~cm})$ were distributed to sub-plot and sub sub-plot, respectively. Control treatment having recommended $\mathrm{N}$ dose without pruned materials (PM) was used to compare the crop yield with that grown in alley cropping system.

\subsection{Woody species and crop establishment}

Saplings of woody species were transplanted during the first week of June. Alley distance was $3 \mathrm{~m}$ wide and the unit plot size was $3 \mathrm{~m} \times 6 \mathrm{~m}$. Distance between trees was $50 \mathrm{~cm}$ for G. sepium, L. leucocephala and $S$. siamea, but it was $25 \mathrm{~cm}$ for $C$. cajan. Thus, the number of stands varied in different alleys depending on the species. All woody species were pruned during the first week of December when they grew vigorously and attained more than one-meter height. Pruned materials (PM) of all woody species were used to record the fresh weight. Pruned materials (PM) were separated into leaf and branches and weighed. Branches were chopped and all PM were incorporated in the respective alley as fresh. Two to three seeds of maize (var. Bornali) were sown into hole on 28 December 1998 maintaining $50 \mathrm{~cm}$ x $25 \mathrm{~cm}$ spacing. 


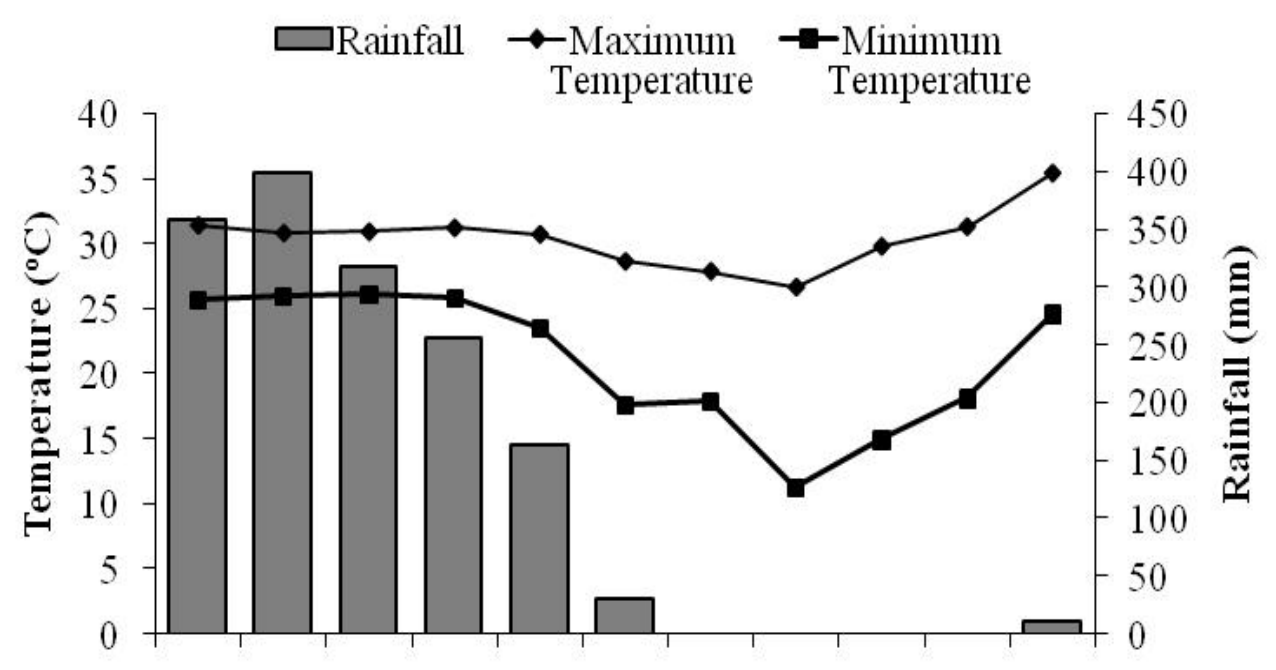

Jun Jul Aug Sep Oct Nov Dec Jan Feb Mar Apr

Month

Fig. 1. Monthly average maximum temperature, minimum temperature and total rainfall in the study area during the experimentation.

Recommended doses (100, 22, 25 and $\left.40 \mathrm{~kg} \mathrm{ha}^{-1}\right)$ N, P, K and Ca were applied. Urea, TSP, MP and gypsum were used as source of $\mathrm{N}, \mathrm{P}, \mathrm{K}$ and $\mathrm{Ca}$, respectively. Except urea, all fertilizers were applied during the final land preparation. In case of urea, one-third was applied during final land preparation and the remaining was applied in two equal installments at 35 and 65 days after sowing. Irrigation, weeding and other intercultural operations were done according to need.

\subsection{Data collection and analysis}

To examine the growth of woody species at different days after pruning (DAP), five plants were selected randomly from each treatment and measurements were done on height and number of branches at 60, 90 and 120 DAP. One linear meter of maize crop was harvested from each row. The grains were air dried (14\% moisture), weighed and yield was estimated. The row in similar position with respect to woody species rows in both sides constituted a pair of row. Initial soil samples were collected before starting the experiment. After experimentation, soils were again collected from alley cropping (0, 50 and $100 \%$ N plus PM) and control treatments. Soil samples were mixed and composite soil samples were made. The samples were then air dried, pulverized, sieved, and used for chemical analysis. Chemical analysis was done for $\mathrm{pH}$ (electrode $\mathrm{pH}$ meter), organic $\mathrm{C}$ (wet combustion method), total $\mathrm{N}$ (micro-kjeldhal method) and cation exchange capacity (CEC) (Achollen Bergen method). Data were subjected to analysis of variance (ANOVA) using IRRISTAT computer program to compare the effects of woody species, distances from woody species and N levels. Duncan's Multiple Range Test (DMRT) was used to compare means of treatments at $5 \%$ level of significance. 

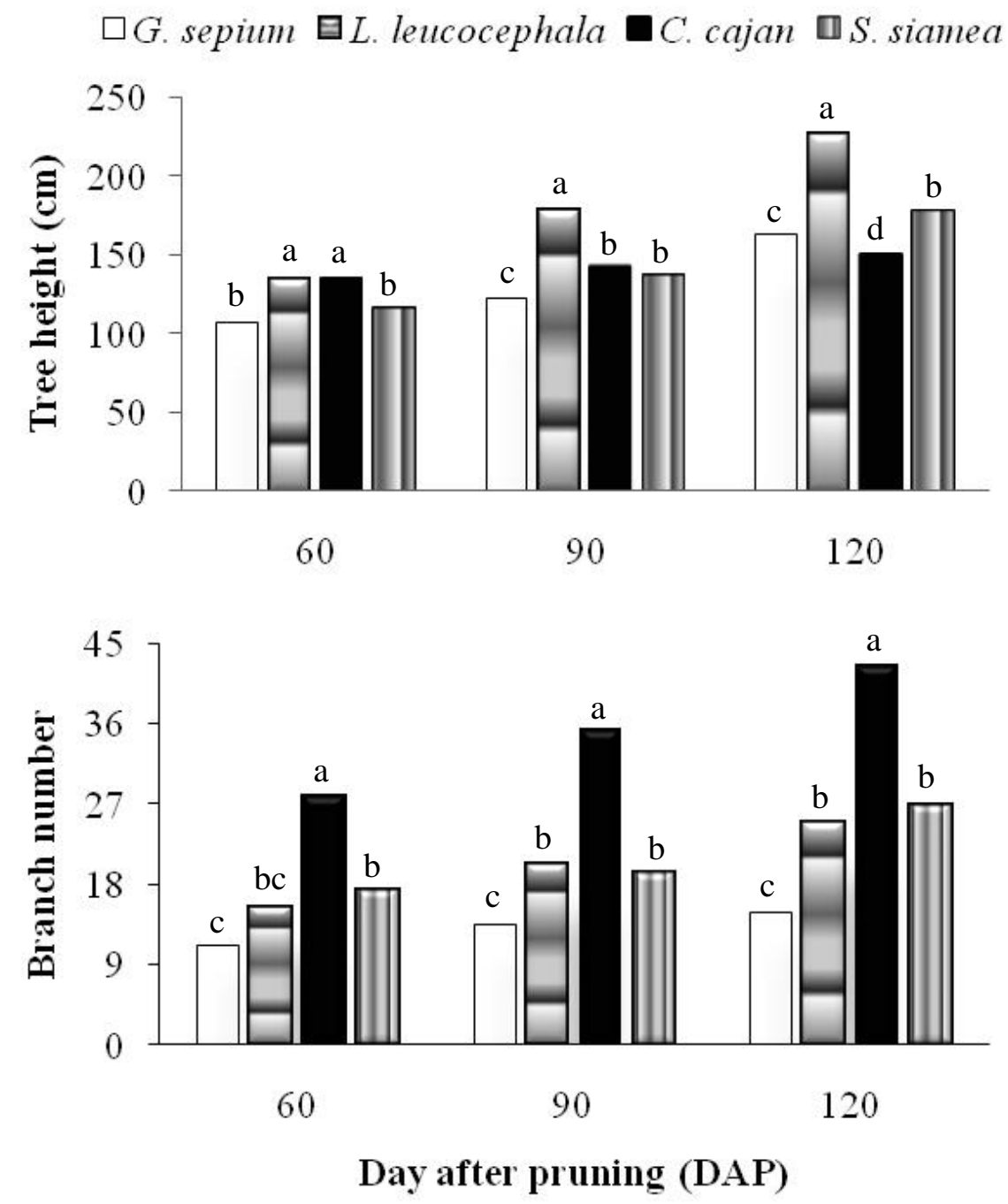

Fig. 2. Performance of four woody species in terms of height and branches at different days after pruning. Means followed by a common letter are not significantly different at the 5\% level by DMRT.

\section{Results and Discussion}

\subsection{Performance of woody species}

Performance of woody species in alley cropping system in terms of height and branch number after pruning (DAP) is presented in Fig 2. Tree height increased with time after pruning. At 60 DAP, though L. leucocephala tree was not distinctly tall but it became significantly taller than other species at 90 and 120 DAP. Initially, the increment rate of $C$. cajan was rapid but it was almost similar at later periods. However, $G$. sepium and $S$. siamea showed same height trend at all measurement dates. At 120 DAP, $L$. leucocephala attained a height of $227 \mathrm{~cm}$, while 
C. cajan dropped from second to fourth position $(149 \mathrm{~cm})$. The slower growth in $C$. cajan may be explained by the sudden cessation of the rainy season and its dwarf nature. The height growth of the other two species was intermediate but $S$. siamea showed faster height growth $(178 \mathrm{~cm})$ over $G$. sepium $(163 \mathrm{~cm})$ species. At all the monitoring dates, $C$. cajan produced significantly higher number of branches compared to the other species, whereas, G. sepium produced remarkably lower number of branches. The number of branches produced by $S$. siamea and $L$. leucocephala were intermediate and closer at all monitoring dates. The mean number of branches produced by $C$. cajan, S. siamea, L. leucocephala and G. sepium at 120 DAP were 43, 27, 25 and 15 , respectively.

\subsection{Pruned materials (PM) produced and added to the soil}

Fresh pruned materials (PM) were separated into leaf and branch and all PM were incorporated to the soil (Fig. 3). The highest amount of leaves $\left(8.9 \mathrm{t} \mathrm{ha}^{-1}\right)$ was pruned from $S$. siamea species, which was closely followed by $C$. cajan $(7.5 \mathrm{t}$ $\mathrm{ha}^{-1}$ ) and $G$. sepium $\left(6.8 \mathrm{t} \mathrm{ha}^{-1}\right)$. Remarkably lower leaf fresh weight was recorded in L. leucocephala $\left(3.0 \mathrm{t} \mathrm{ha}^{-1}\right)$. In case of branch, the trend was different where $G$. sepium produced maximum $\left(3.7 \mathrm{t} \mathrm{ha}^{-1}\right)$ followed by L. leucocephala $(3.1 \mathrm{t}$ $\left.\mathrm{ha}^{-1}\right)$. However, branch fresh weight obtained from $C$. cajan and $S$. siamea was almost similar. The highest amount of total fresh PM of $11.7 \mathrm{t}$ $\mathrm{ha}^{-1}$ was recorded in $S$. siamea species, which was almost similar to $G$. sepium $\left(10.5 \mathrm{t} \mathrm{ha}^{-1}\right)$ and $C$. cajan $\left(10.2 \mathrm{t} \mathrm{ha}^{-1}\right)$, whereas it was significantly lower in L. leucocephala $\left(6.1 \mathrm{t} \mathrm{ha}^{-1}\right)$.

\subsection{Grain yield}

The grain yield of maize grown in alleys was influenced significantly $(\mathrm{P}<0.05)$ by nitrogen levels (Table 1). Grain yield generally increased with the increase in applied $\mathrm{N}$ levels. The mean highest grain yield $\left(4.15 \mathrm{tha}^{-1}\right)$ was obtained from $100 \% \mathrm{~N}$ plus PM treatment, which was followed by control $\left(4.08 \mathrm{t} \mathrm{ha}^{-1}\right)$ and $75 \% \mathrm{~N}$ plus PM (3.94 $\mathrm{t}$ $\left.\mathrm{ha}^{-1}\right)$, while the lowest grain yield $\left(1.64 \mathrm{t} \mathrm{ha}^{-1}\right)$ was found in no $\mathrm{N}$ but PM applied treatment. The effect of different woody species on grain yield was insignificant at their respective $\mathrm{N}$ levels, except $25 \% \mathrm{~N}$ plus PM treatment. At $25 \% \mathrm{~N}$ plus PM treatment, grain yield of maize produced in $S$. siamea alley was significantly lower compared to G. sepium but statistically identical to other species. The result indicates that by using $25 \%$ less $\mathrm{N}$ fertilizer, it is possible to get desired yield in alley cropping system. The result also suggests that the system would work more effectively if $\mathrm{N}$ fertilizer is used. Korwar and Radder (1997) reported $\mathrm{N}$ as limiting factor and observed higher sorghum yield when $\mathrm{N}$ was applied along with PM in alley cropping system. They observed that alley cropping decreased sorghum yield by $28 \%$ when L. leucocephala PM was removed and increased by $21 \%$ when $1.92 \mathrm{t} \mathrm{ha}^{-1} \mathrm{PM}$ was applied to the soil annually. Aihou et al. (1999) reported $107 \%$ more maize yield in alley cropping on the degraded site.

Lignin is considered by many to be the most important component for determining the rate of decomposition of prunings (Meentemeyer, 1978). Leaves of $G$. sepium contain high nutrients, low $\mathrm{C} / \mathrm{N}$ ratio and lignin (Baggie et al., 2000) indicating high quality of leaves with fast decomposition rate. Tossah et al. (1999) observed higher $\mathrm{N}$ accumulation of $G$. sepium prunings compared to L. leucocephala and S. siamea in alley cropping experiment. Nutrients released from PM to the soil might be utilized by the maize crop and ultimately increased the yield. Maize grain yield grown in G. sepium alley was about 2.82, 4.13 and $5.81 \%$ higher over L. leucocephala, $C$. cajan and $S$. siamea alleys, respectively. Anthofer et al. (1998) reported higher crop yield in the G. sepium alley explaining the fastest decomposition and nutrient release of added PM. The relatively poor yield of maize in the alleys of $S$. siamea was due to heavy branching, root completion (Hauser, 1993) and slower decomposition rate of $\mathrm{PM}$ and non $\mathrm{N}$-fixing nature (Vanlauwe et al., 1997). 
Table 1. Grain yield $\left(\mathrm{t} \mathrm{ha}^{-1}\right)$ of maize grown in alleys consisting of four different woody species as affected by different nitrogen levels along with pruned materials.

\begin{tabular}{lccccc}
\hline Treatment & \multicolumn{5}{c}{ Woody species } \\
\cline { 2 - 5 } $\begin{array}{l}\text { Nitrogen dose }(\%) \\
+ \text { PM* }\end{array}$ & G. sepium & L. leucocephala & C. cajan & S. siamea & Mean \\
\hline $0+\mathrm{PM}$ & $1.73 \mathrm{dA}$ & $1.67 \mathrm{dA}$ & $1.68 \mathrm{dA}$ & $1.94 \mathrm{dA}$ & $1.64 \mathrm{~d}$ \\
$25+\mathrm{PM}$ & $2.83 \mathrm{cA}$ & $2.71 \mathrm{cAB}$ & $2.69 \mathrm{cAB}$ & $2.50 \mathrm{cB}$ & $2.68 \mathrm{c}$ \\
$50+\mathrm{PM}$ & $3.51 \mathrm{bA}$ & $3.42 \mathrm{bA}$ & $3.39 \mathrm{bA}$ & $3.31 \mathrm{bA}$ & $3.41 \mathrm{~b}$ \\
$75+\mathrm{PM}$ & $4.03 \mathrm{aA}$ & $3.95 \mathrm{aA}$ & $3.90 \mathrm{aA}$ & $3.76 \mathrm{abA}$ & $3.94 \mathrm{ab}$ \\
$100+\mathrm{PM}$ & $4.28 \mathrm{aA}$ & $4.20 \mathrm{aA}$ & $4.11 \mathrm{aA}$ & $4.01 \mathrm{aA}$ & $4.15 \mathrm{a}$ \\
100 (Control)** & $4.08 \mathrm{a}$ & $4.08 \mathrm{a}$ & $4.08 \mathrm{a}$ & $4.08 \mathrm{a}$ & $4.08 \mathrm{ab}$ \\
\hline
\end{tabular}

* Pruned materials $(\mathrm{PM}) ; * *$ Without tree and PM

In a column, means ( $\mathrm{N}$ levels) followed by a common small letter, and in a row, means (tree species) followed by a common capital letter are not significantly different at the $5 \%$ level by DMRT.

Table 2. Spatial variation of grain yield $\left(\mathrm{t} \mathrm{ha}^{-1}\right)$ of maize across the alley as influenced by different woody species.

\begin{tabular}{lcccc}
\hline \multirow{2}{*}{ Tree species } & \multicolumn{4}{c}{ Distance from the tree base $(\mathrm{cm})$} \\
\cline { 2 - 5 } & 50 & 100 & 150 & Mean \\
\hline G. sepium & $3.14 \mathrm{aB}$ & $3.29 \mathrm{aAB}$ & $3.34 \mathrm{aA}$ & $3.28 \mathrm{a}$ \\
L. leucocephala & $3.03 \mathrm{abB}$ & $3.22 \mathrm{aAB}$ & $3.32 \mathrm{aA}$ & $3.19 \mathrm{ab}$ \\
C. cajan & $2.94 \mathrm{abB}$ & $3.18 \mathrm{aAB}$ & $3.34 \mathrm{aA}$ & $3.15 \mathrm{ab}$ \\
S. siamea & $2.86 \mathrm{bB}$ & $3.10 \mathrm{aA}$ & $3.20 \mathrm{aA}$ & $3.10 \mathrm{~b}$ \\
Mean & $2.99 \mathrm{~B}$ & $3.19 \mathrm{~A}$ & $3.31 \mathrm{~A}$ & \\
\hline
\end{tabular}

In a column, means (tree species) followed by a common small letter, and in a row, means (distance) followed by a common capital letter are not significantly different at the 5\% level by DMRT.

Table 3. Soil properties change in alley cropping system as influenced by incorporation of prune materials of four different woody species after harvesting maize.

\begin{tabular}{lcccc}
\hline \multicolumn{1}{c}{ Treatment } & $\mathrm{pH}$ & Organic C $(\%)$ & Total N (\%) & CEC $\left(\mathrm{meq}^{\left.100 \mathrm{~g}^{-1}\right)}\right.$ \\
\hline L. leucocephala & & & & \\
C. cajan & $6.1 \mathrm{a}$ & $0.68 \mathrm{a}$ & $0.081 \mathrm{a}$ & $20.32 \mathrm{ab}$ \\
S. siamea & $6.1 \mathrm{a}$ & $0.67 \mathrm{a}$ & $0.079 \mathrm{ab}$ & $19.95 \mathrm{bc}$ \\
Control & $6.0 \mathrm{a}$ & $0.67 \mathrm{a}$ & $0.079 \mathrm{ab}$ & $19.92 \mathrm{bc}$ \\
Initial & $5.8 \mathrm{a}$ & $0.58 \mathrm{c}$ & $0.070 \mathrm{c}$ & $19.21 \mathrm{~d}$ \\
\hline
\end{tabular}

Means followed by a common letter are not significantly different at the 5\% level by DMRT. 


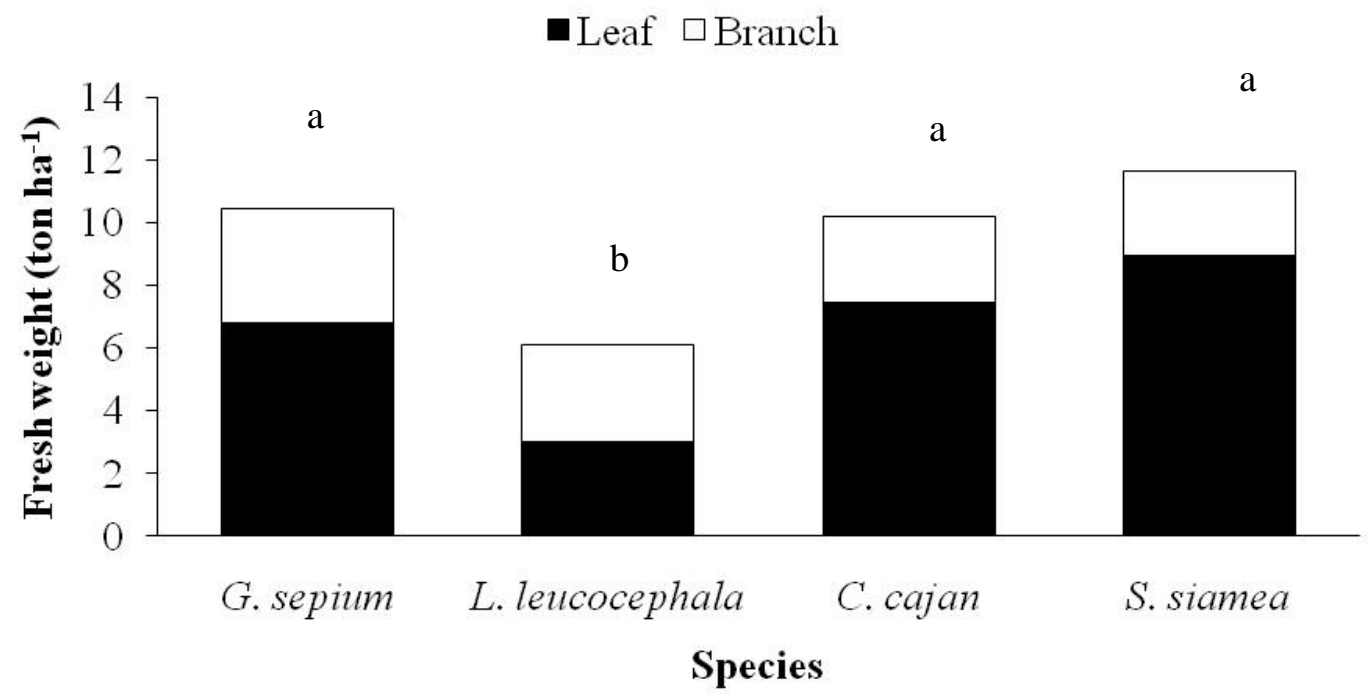

Fig. 3. Fresh weight of pruned materials (leaves and branches) obtained from the woody species and added to the soil. Means followed by a common letter are not significantly different at the 5\% level by DMRT.

Table 2 shows the spatial variation in maize grain yield across the alley as influenced by woody species and distances from the base. The highest mean grain yield $\left(3.28 \mathrm{t} \mathrm{ha}^{-1}\right)$ was noted in $G$. sepium alley, which was closely followed by $L$. leucocephala $\left(3.19 \mathrm{t} \mathrm{ha}^{-1}\right)$ and $C$. cajan $(3.15$ ton $\left.\mathrm{ha}^{-1}\right)$ alley, while the lowest grain yield (3.10 t $\mathrm{ha}^{-1}$ ) was produced in $S$. siamea alley and this yield was also identical to the grain yield produced in C. cajan and L. leucocephala alleys. It was noticed that maize yield was adversely affected when grown in the closest $(50 \mathrm{~cm})$ row position irrespective of woody species. The highest mean (average of four woody alleys) grain yield of maize $\left(3.31 \mathrm{tha}^{-1}\right)$ was observed at $150 \mathrm{~cm}$ row position from the tree base, which was closely followed by $100 \mathrm{~cm}$ row position $\left(3.13 \mathrm{t} \mathrm{ha}^{-1}\right)$. However, the grain yield $\left(2.99 \mathrm{tha}^{-1}\right)$ was significantly lower at $50 \mathrm{~cm}$ row position. In G. sepium, L. leucocephala and C. cajan alleys, although the lowest yields of maize were observed at the $50 \mathrm{~cm}$ row position, but they did not vary significantly with that grown at the next row position $(100 \mathrm{~cm})$. Yield reduction at the closer row from the base of woody species might be due to competition for light, water and nutrients between woody species and crop. Similar results were obtained by others Friday and Fownes, 2002; Miller and Pallardy 2001 in maize production with alley cropping.

\subsection{Changes in chemical properties of the soil}

The soil chemical properties before and after the harvest of maize are presented in Table 3 . Soil $\mathrm{pH}$ did not vary significantly among the treatments, which varied from 5.8 to 6.1 . Variation in organic C content among the alley treatments was insignificant, but this was significantly higher than initial and control soils. The highest $(0.69 \%)$ and lowest $(0.58 \%)$ organic $\mathrm{C}$ contents were noted in $G$. sepium alley and control soils, respectively. The highest total $\mathrm{N}$ content of soil $(0.081 \%)$ was observed in L. leucocephala alley, which was followed by other alleys $(0.079,0.077$ and $0.076 \%$ in G. sepium, C. cajan and S. siamea alleys, respectively), but this was significantly higher than those in initial $(0.076 \%)$ and control $(0.070 \%)$ soils. However, total $\mathrm{N}$ content in alleys, except L. leucocephala, did not change 
remarkably compared to initial soil. CEC content was the highest in G. sepium alley soil $(50.57 \mathrm{meq}$ $100 \mathrm{~g}^{-1}$ ), which did not vary remarkably in $L$. leucocephala alley (20.32 meq $\left.100 \mathrm{~g}^{-1}\right)$, but varied significantly over C. cajan (19.95 meq $100 \mathrm{~g}^{-1}$ ) and $S$. siamea (19.92 meq $\left.100 \mathrm{~g}^{-1}\right)$ alleys. Although, the lowest value of CEC (19.21 meq $100 \mathrm{~g}^{-1}$ ) was recorded in control soil, it did not vary much with initial soil (19.56 meq $\left.100 \mathrm{~g}^{-1}\right)$. The increase in soil $\mathrm{pH}$ under G. sepium may be due to its faster leaf decomposition and higher foliar Ca levels. Miah et al. (1997) observed higher soil $\mathrm{pH}$ and organic $\mathrm{C}$ in alley cropping system with G. sepium. Higher N content in the $L$. leucocephala alley might be due to higher $\mathrm{N}$-fixing ability (100-500 kg ha ${ }^{-1}$ year $^{-1}$ ) of the species (Nair, 1993) and higher leaf $\mathrm{N}$ content (Anthofer et al., 1998). CEC was also higher in the alley cropping treatments compared to control and initial soils. Increased top-soil CEC in alley cropping of the present study is supported by De Costa et al. (2005).

\section{Conclusions}

The results of the study indicate that $L$. leucocephala maintained tallness and C. cajan produced the highest branches. Higher pruned materials were obtained and added to the soil in $S$. siamea, G. sepium and C. cajan alleys. However, $25 \%$ chemical $\mathrm{N}$ can be saved if maize is grown in alley cropping system with $G$. sepium, $L$. leucocephala, $C$. cajan and S. siamea. Maize yield, however, was relatively better in G. sepium alley over other woody species. Soil properties changed in a positive direction in alley cropping plots particularly G. sepium and L. leucocephala alleys compared to control and initial soils.

\section{References}

Aihou, K., N. Sanginga, B. Vanlauwe, O. Lyasse, J. Diels and R. Merckx. 1999. Alley cropping in the moist savanna of West-Africa: I. Restoration and maintenance of soil fertility on 'terre de barre' soils in Benin Republic. Agroforestry Systems. 42: 213-227.

Anthofer, J., J. Hanson and S.C. Jutzi. 1998. Wheat growth as influenced by application of agroforestry tree prunings in Ethiopian highlands. Agroforestry Systems. 40: 1-18.

Baggie, I., F. Zapata, N. Sanginga, and S.K.A. Danso. 2000. Ameliorating acid infertile rice soil with organic residue from nitrogen fixing trees. Nutrient Cycling in Agroecosystems. 57: 183-190.

BARC. 2005. Fertilizer Recommendation Guide-2005, Bangladesh Agricultural Research Council, Dhaka, Bangladesh, p. 48.

BBS 1998. Statistical Year Book of Bangladesh, Bangladesh Bureau of Statistics, People's Republic of Bangladesh, p. 352.

Chamshama, S. A. O., A. G. Mugasha, A. Klovstad, O. Haveraaen and S.M.S. Maliondo. 1998. Growth and yield of maize alley cropped with Leucaena leucocephala and Faidherbia albida in Morogoro, Tanzania. Agroforestry Systems. 40: 215-225.

De Costa W. A. J. M. and P. Surenthran. 2005. Tree-crop Interactions in hedgerow intercropping with different tree species and tea in Sri Lanka: 1. Production and resource competition. Agroforestry Forum. 63: 199-209.

Friday, J. B. and J. H. Fownes. 2002. Competition for light between hedgerow and maize in an alley cropping system in Hawaii, USA. Agroforestry Systems. 55: 125-137.

Harwood R.R. 1990. A history of sustainable agriculture. In: Sustainable Agricultural Systems (eds. Edwards, C.A., Lal, R., Madden, P., Miller, R.H. and House, G.). pp. 3-19. St. Lucie Press, Delray Beach, Florida.

Hauser, S. 1993. Root distribution of Dactyladenia (Acioa) barteri and Senna (Cassia) siamea in alley cropping on Ultisol. I. Implication for field experimentation. Agroforestry Systems. 24: 111-121.

Hossain, S. M. A. \& Kashem, M. A. 1997. Management combat declining soil fertility in Bangladesh. Keynote paper. Proc. of the 
$6^{\text {th }}$ Biennial Conference of the Bangladesh Soc. Agron. Held on 29 Jully 1997. pp. 22-39.

Jordan, C.F. 2004. Organic farming and agroforestry: Alley cropping for mulch production for organic farms of southeastern United States. Agroforestry Systems. 61:79-90.

Kang, B.T., G.F. Wilson and T.L. Lawson. 1984. Alley cropping: a stable alternative to shifting cultivation. IITA, Ibadan, Nigeria. pp. 12-15.

Korwar, G.R. and G.D. Radder. 1997. Alley cropping of sorghum with Leucaena leucocephala during the post rainy season on Vertisols in semi-arid India. Agroforestry Systems. 37: 265-277.

Meentemeyer, V. 1978. Macroclimate and lignin control of litter decomposition rates. Ecology. 59: 465-472

Miah, M.G. 1993. Performance of selected multipurpose tree species and field crops grown in association as affected by tree branch pruning. PhD dissertation (Crop Science-Agronomy).CLSU, Philippines.
Miah, M.G., D.P. Garrityand and M.L. Aragon. 1997. Effect of legume trees on soil chemical properties under agroforestry system. Annuls of Bangladesh Agriculture. 7(2): 95-103.

Millar A.W. and S.G. Pallardy. 2001. Resource competition across the crop-tree interface in a maize-silver maple temperate alley cropping stand in Missouri. Agroforestry Systems. 53: 247-259.

Nair, P.K.R. 1993. An Introduction to Agroforestry. Kluwer Academic Publishers in cooperation with International Centre for Research in Agroforestry (ICRF), p. 315.

Tossah, B. K., D.K. Zamba, B. Vanlauwe, N. Sanginga, O. Lyasse, J. Diels and R. Merckx. 1999. Alley cropping in the moist Savanna of West Africa: Impact on soil productivity in a North-to-South transects in Togo. Agroforestry Systems. 42: 229-244.

Vanlauwe, B., N. Sanginga and R. Merckx. 1997. Decomposition of four Leucaena and Senna prunings in alley cropping systems under sub-humid tropical conditions: the process and its modifiers. Soil Biology and Biochemistry. 29: 131-137. 